\title{
Gene expression programming and artificial neural network to estimate atmospheric temperature in Tabuk, Saudi Arabia
}

\author{
H. Md. Azamathulla ${ }^{1,4}$. Upaka Rathnayake ${ }^{2} \cdot$ Ahmad Shatnawi $^{3}$
}

Received: 11 April 2018 / Accepted: 19 September 2018 / Published online: 27 September 2018

(C) The Author(s) 2018

\section{Abstract}

Climate change is not a myth. There is enough evidence to showcase the impact of climate change. Town planners and authorities are looking for potential models to predict the climatic factors in advance. Being an agricultural area in Saudi Arabia, Tabuk region gets greater interest in developing such a model to predict the atmospheric temperature. Therefore, this paper presents two different studies based on artificial neural networks (ANNs) and gene expression programming (GEP) to predict the atmospheric temperature in Tabuk. Atmospheric pressure, rainfall, relative humidity and wind speed are used as the input variables in the developed models. Multilayer perceptron neural network model (ANN model), which is high in precession in producing results, is selected for this study. The GEP model that is based on evolutionary algorithms also produces highly accurate results in nonlinear models. However, the results show that the GEP model outperforms the ANN model in predicting atmospheric temperature in Tabuk region. The developed GEP-based model can be used by the town and country planers and agricultural personals.

\section{Graphical abstract}

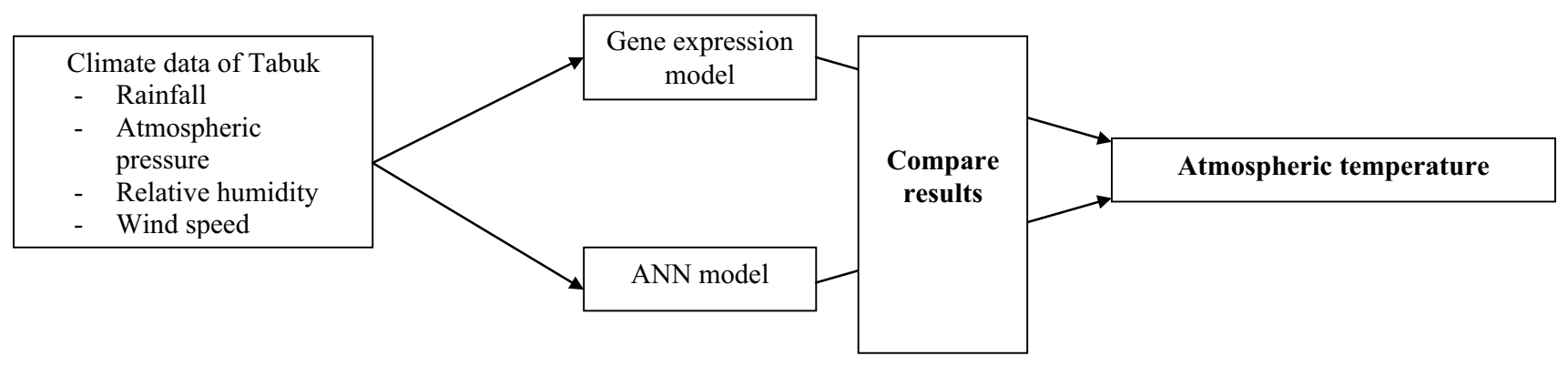

Keywords Artificial neural network $\cdot$ Atmospheric temperature $\cdot$ Climate change $\cdot$ Gene expression programming $\cdot$ Tabuk

Upaka Rathnayake

upakasanjeewa@gmail.com

H. Md. Azamathulla mdazmath@gmail.com

Ahmad Shatnawi

ashatnawi@ut.edu.sa
2 Department of Civil Engineering, Sri Lanka Institute of Information Technology, Malabe 10115, Sri Lanka

3 Department of Civil Engineering, University of Tabuk, Tabuk 71491, Saudi Arabia

4 Present Address: The University of the West Indies, St. Augustine campus, St. Augustine, Trinidad and Tobago

Department of Civil Engineering and Sensor Networks and Cellular Systems (SNCS) Research Center, University of Tabuk, Tabuk 71491, Saudi Arabia 


\begin{tabular}{ll}
\multicolumn{2}{l}{ Abbreviations } \\
ANN & Artificial neural network \\
GEP & Gene expression programming \\
$P$ & Atmospheric pressure \\
$R^{2}$ & Coefficient of determination \\
RF & Rainfall \\
RH & Relative humidity \\
TEMP & Mean temperature \\
WS & Wind speed
\end{tabular}

\section{Introduction}

Climate change is an extremely important topic. Modern climate change is heavily influenced by human activities (Karl and Trenberth 2003). Human activities that lead to emit various gases to atmosphere have increased the rate of climate change. Energy source-related emission is one of the largest factors to influence the climate change. The energy source emissions can even reach $80 \%$ of total greenhouse gas emissions (Quadrelli and Peterson 2007). Carbon dioxide $\left(\mathrm{CO}_{2}\right)$ emission to the atmosphere has reached the highest level ever recorded in the recent decade. However, not only $\mathrm{CO}_{2}$ but also some other gases contribute to the greenhouse effect and then to climate change. Water vapor, methane and ozone are few examples for these other gases (Karl and Trenberth 2003).

The climate change has impacted not only human life (Barnett and Adger 2007; Haines et al. 2006; Patz et al. 2005; Vorosmarty 2000) but also other living species in the world, including plants (Harvell et al. 2009; Hughes 2003; Mawdsley et al. 2009; Root et al. 2003). World Health Organization estimated that there are around 150,000 deaths during the 30 years (Patz et al. 2005). Many deaths out of them were linked to climate fluctuations. Climate change even has imposed worse impacts on extinct animals (Malcolm et al. 2006; McDonald and Brown 1992; Pounds et al. 2006; Sekercioglu et al. 2007).

Atmospheric temperature is one of the most significant climatic factors, in which the human body feels. Therefore, even a small change is influenced to the daily routine of the people (Kalkstein and Smoyer 1993). Therefore, analysis of atmospheric temperature takes a significant interest from the researchers throughout the world (Mears and Wentz 2017; Rotstayn et al. 2014; Santer et al. 2012; Simmons et al. 2014). Trend analysis of atmospheric is one of the most influenced research areas. Many researchers performed temperature trend analysis and predicted on the future scenarios (Forster et al. 2013; Lee et al. 2013; Marotzke and Forster 2015; Shaltout and Omstedt 2014). These present the increase in surface temperature patterns in the future for most of the parts of the world. Atmospheric temperature trend analysis has taken place in Middle Eastern region too, including Saudi Arabia (Alghamdi and Moore 2014; Almazroui et al. 2013; Athar 2013; Krishna 2014). However, this kind of research was not extended to Tabuk area in Saudi Arabia. Therefore, there is a clear research gap along the lines of temperature trends in Tabuk area.

In addition, usage of gene expression programming (GEP) and artificial neural networks (ANN) is very famous on estimating various climatic parameters. Many researchers used these techniques to estimate incoming solar radiation (Landeras et al. 2012), daily reference evapotranspiration (Guven et al. 2008; Izadifar and Elshorbagy 2010; Yassin et al. 2016), evaporation (Shiri et al. 2012), dew point temperature (Shiri et al. 2014), etc. Basically, an unknown or unmeasured climatic parameter was estimated by using the other climatic parameters using GEP and ANN. However, there is no literature on the usage of these techniques to Tabuk, Saudi Arabia. Therefore, the area is clearly under a research gap as Tabuk is an important agricultural area in Saudi Arabia. This paper presents the results from a GEP model to estimate the atmospheric temperature in Tabuk area using the other climatic parameters. In addition, an ANN model is developed to obtain the atmospheric temperature in the same area, and then, results are compared against the estimations by GEP model and the real recorded data.

\section{Overview of ANN and GEP}

ANN and GEP are two of the most widely used branches of soft computing techniques in hydraulic engineering. ANNs have been reported to provide reasonably acceptable solutions for problems in water resources and hydraulic engineering; particularly, they execute results for highly nonlinear and complex water resource problems (Azmathullah et al. 2006; Bilhan et al. 2010; Haghiabi et al. 2017; Kisi et al. 2008; Parsaie and Haghiabi 2015, 2018; Parsaie et al. 2018a). During the last three decades, researchers have noticed that the use of soft computing techniques as alternative to conventional statistical methods based on controlled laboratory or field data yield significantly better results. For example, Azamathulla et al. (2005, 2006, 2008, 2016), Guven and Gunal (2008a) and Kisi et al. (2008) have shown that these predictive approaches such as artificial neural networks (ANNs) yield effective estimates to the scour around the hydraulic structures. In addition, GP has shown agreeable estimates to the similar problems (Azamathulla et al. 2010; Guven and Gunal 2008a, b; Guven and Aytek 2009).

Artificial neural networks are basically a collection of simple processing elements (PEs) arranged into input layer, output layer and usually one or more hidden layers. The multilayer perceptron (MLP) is a class of feedforward ANN and usually uses a sigmoid-type function for each PE (Parsaie et al. 2018b). Sigmoid-type functions are bound, monotonic 
and non-decreasing functions with a nonlinear response. They are good at simulating any nonlinear processes.

On the other hand, gene expression programs (GEPs) are evolutionary algorithms following extensions to genetic programs (Koza 1999; Parsaie et al. 2017). The computer programs of GEP are all encoded in linear chromosomes, which are then expressed or translated into expression trees (ETs). ETs are sophisticated computer programs that are usually evolved to solve a particular problem, and selected according to their fitness at solving that problem. GEPs are a full-fledged genotype-phenotype system where the genotype is separated from the phenotype. In contrast, GPs are replicator systems. Therefore, solving power of GEP is greatly enhanced compared to GP (Ferreira 2001). GEP initializes the solution search process by initializing the population in which the chromosomes of each individual are randomly generated. These chromosomes are individually evaluated based on a fitness function and then reproduce with modifications. The reproduction process is repeated until the GEP reached a predefined number of generations or until a solution is achieved.

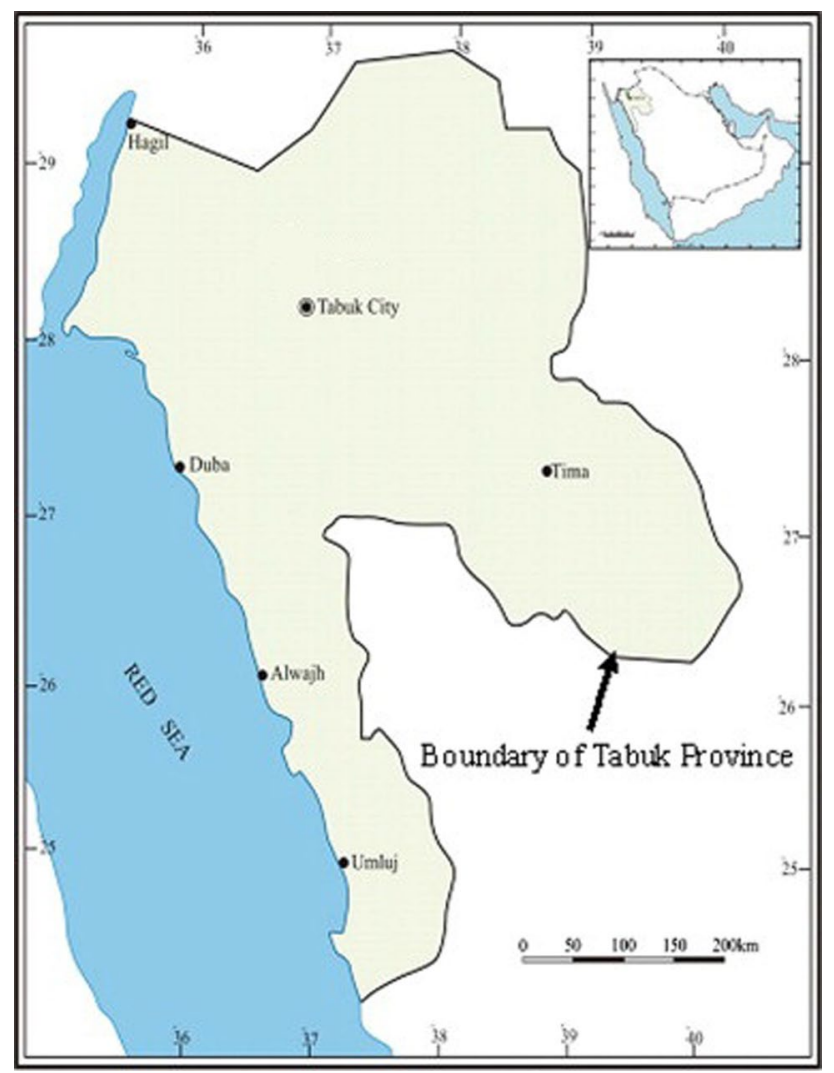

Fig. 1 Study area (source: Al-Harbi 2010)

\section{Study area}

As it is stated in introduction, the study of the climate change is crucial because it enables us to know the factors that affect weather. This knowledge can be useful in the quest to limit the negative aspects of climate change. The emission of inert gasses such as carbon dioxide and methane increases temperature causing harmful influence on water evaporation percentage and ultimately decreases groundwater stock. Tabuk is located in the northwestern part of Saudi Arabia. It has an area of $139,000 \mathrm{~km}^{2}$ (Fig. 1) and was bounded in north to Saudi-Jordan country border, in south and west to Red Sea and in east to Hufa depression. The average height of the city area is $770 \mathrm{~m}$ from mean sea level. Tabuk is classified as a hyper-arid catchment (Abushandi and Alatawi 2015). It has a high evaporation rate with a low vegetation cover. In addition, the area is popular for flash floods due to unexpected rainfalls. Tabuk has two seasons: shorter winter season and a longer summer season. The average annual rainfall is $33 \mathrm{~mm}$ and can be seen in the winter season from October to April.

Despite the arid climate in Tabuk, it is an agricultural area that relies heavily on little rainwater received and extracted groundwater. Therefore, any change in the water resources would be devastating for the agricultural industry. Al-Harbi (2010) reported that the agricultural land extent in Tabuk was increased by $10 \%$ for the 20 years from 1988 to 2008 .

\section{Methodology}

Monthly weather data for 30 years (1986-2015) were collected from the Saudi General Authority of Meteorology and Environmental Protection. Rainfall, wind speed, air pressure, humidity and atmospheric temperature were among the collected data. These data were used to calibrate and validate the ANN and GEP models. The summary of the gathered data is given in Table 1 .

The overall objective of this research work is to find the atmospheric temperature of Tabuk using the other climatic factors. These minimum, maximum and mean values of monthly rainfall, relative humidity, wind speed, atmospheric temperature and atmospheric pressure data were fed as the

Table 1 Monthly average climatic data for 30 years (1986-2015)

\begin{tabular}{lllr}
\hline Parameter & Minimum & Maximum & Average \\
\hline Rainfall (mm/month) & 0 & 75.6 & 2.5 \\
Relative humidity (\%) & 16 & 62 & 32.9 \\
Wind speed (m/s) & 3 & 9 & 5.5 \\
Atmospheric pressure at & 916.3 & 932 & 925.8 \\
weather station (mbar) & & & \\
\hline
\end{tabular}


inputs of the ANN model. Each data set was randomly partitioned into two sets, where $80 \%$ of data out of 30 years data were used for model calibration (training), while the other $20 \%$ was used for validation (testing). We developed an ANN model based on multilayer perceptron neural network architecture. The ANN model was trained using the Neural Network Toolbox in MATLAB. The Levenberg-Marquardt algorithm is used in this toolbox. The coefficient of determination $\left(R^{2}\right)$ and the mean squared error (MSE) were used to test the developed ANN model.

In addition to the ANN model to predict the atmospheric temperature in Tabuk, we developed a GEP model. Therefore, the two developed models can be compared for their results and accuracy. GEP was also used to estimate the atmospheric temperature using the other climatic factors. Similar to the ANN modeling, we use $80 \%$ of the climatic data what we obtained for the training set. The remaining $20 \%$ of the data were used to the testing set. The training set defines the learning environment of the GEP system. First, the fitness function was chosen. The chosen fitness function for this problem is given in the following equation (Eq. 1).

$f_{i}=\sum_{j=1}^{C_{t}}\left(M-\left|C_{i, j}-T_{j}\right|\right)$

where $M$ is the range of selection, $C_{i, j}$ is the value returned by the individual chromosome $i$ for fitness case $j$ and $T_{j}$ is the target value for fitness case $j .\left|C_{i, j}-T_{j}\right|$ is the precision of the fitness function. If it is less than 0.01 , then the precision is considered zero and $f_{i}$ reaches to its maximum; $f_{\max }=C_{t} M$. In this problem $M=100$ was used. In this case, $f_{\max }=1000$. The fitness function in Eq. 1 allows finding the optimal solutions by itself. This is one of the main advantages of having such a fitness function. In addition, the simulation continues until it reaches the maximum of the fitness function value. Next, the set of terminals $(T)$ and the set of functions $(F)$ were chosen to create the chromosomes. Set of terminals for this problem consists of single variable of atmospheric temperature and follows the following equation (Eq. 2).

$\mathrm{TEMP}=f(\mathrm{WS}, P, \mathrm{RH}, \mathrm{RF})$

where TEMP is the atmospheric temperature and WS, $P$, RH and RF are for wind speed, atmospheric pressure, relative humidity and rainfall, respectively. The choice of the appropriate function given in Eq. 2 is not straightforward. However, a good guess can always be helpful. We have used five basic arithmetic operators $(+,-, \times, /$, power $)$ in connecting the parameters to introduce the function for TEMP.

Then, the chromosomal architecture was selected. Chromosomal architecture consists of the length of the head and the number of genes. The chromosomes with three genes (length of $9, t=9)$ with head length of $8(h=8)$ were selected. The length of the chromosome is, therefore, 30 . Linking of the $f$ functions is done using the addition arithmetic function. The literature shows that the addition gives better results (Azmathullah et al. 2005). These selected functions are given in the following equations (Eqs. 3-6).

$T=\left(\frac{4.667 \times \mathrm{RH}^{3}}{P}\right)^{4}+\left(\frac{\mathrm{RH}}{10}\right)^{5}$

$T=T+(6.32 \times \mathrm{RH} \times(-\mathrm{RF}) \times \mathrm{WS} \times \sqrt{P})$

$T=T+\left(\mathrm{RH}-P-\mathrm{WS}-472\left(\mathrm{RH} \times \mathrm{RF} \times \mathrm{WS} \times P^{4}\right)\right)$

$T=T+\left(1.01549(\mathrm{RH}+P)+\frac{2 P}{3}+0.516+4.62(\mathrm{RF} \times P)^{4}\right)$

Therefore, Eq. 2 can be expanded using the combination of Eqs. 3-6 and can be presented in Eq. 7. This equation is obtained from the developed GEP model.

$$
\begin{aligned}
\text { TEMP }= & \left(\frac{4.667 \times \mathrm{RH}^{3}}{P}\right)^{4}+\left(\frac{\mathrm{RH}}{10}\right)^{5} \\
& +(6.32 \times \mathrm{RH} \times(-\mathrm{RF}) \times \mathrm{WS} \times \sqrt{P}) \\
& +\left(\mathrm{RH}-P-\mathrm{WS}-472\left(\mathrm{RH} \times \mathrm{RF} \times \mathrm{WS} \times P^{4}\right)\right) \\
& +\left(1.01549(\mathrm{RH}+P)+\frac{2 P}{3}+0.516+4.62(\mathrm{RF} \times P)^{4}\right)
\end{aligned}
$$

A combination of genetic operators (mutation, crossover and transposition) was used to set variations of the data set. As it was stated earlier, 288 out of 360 data sets $(80 \%)$ were used to train the GEP model and the remaining $72(20 \%)$ data sets were used to test the GEP model.

\section{Results and discussion}

Figure 2 shows the results obtained from the developed artificial neural network model. The observed atmospheric temperature data were compared to the predicted atmospheric temperature data from ANN model. The best fit line is the $45^{0}$ inclination line ( $Y=X$ line or predicted temperature $=$ observed temperature). The results show that they are more biased to the $-25 \%$ of the best fit line. Therefore, the developed ANN model for predicting atmospheric temperature for Tabuk, Saudi Arabia, is under predicting the results. This clearly shows from the $R^{2}$ value $\left(R^{2}=0.67\right)$ for the results. 
Fig. 2 Predicted temperature using ANN against the observed temperature
Fig. 3 Predicted temperature using GEP against the observed temperature
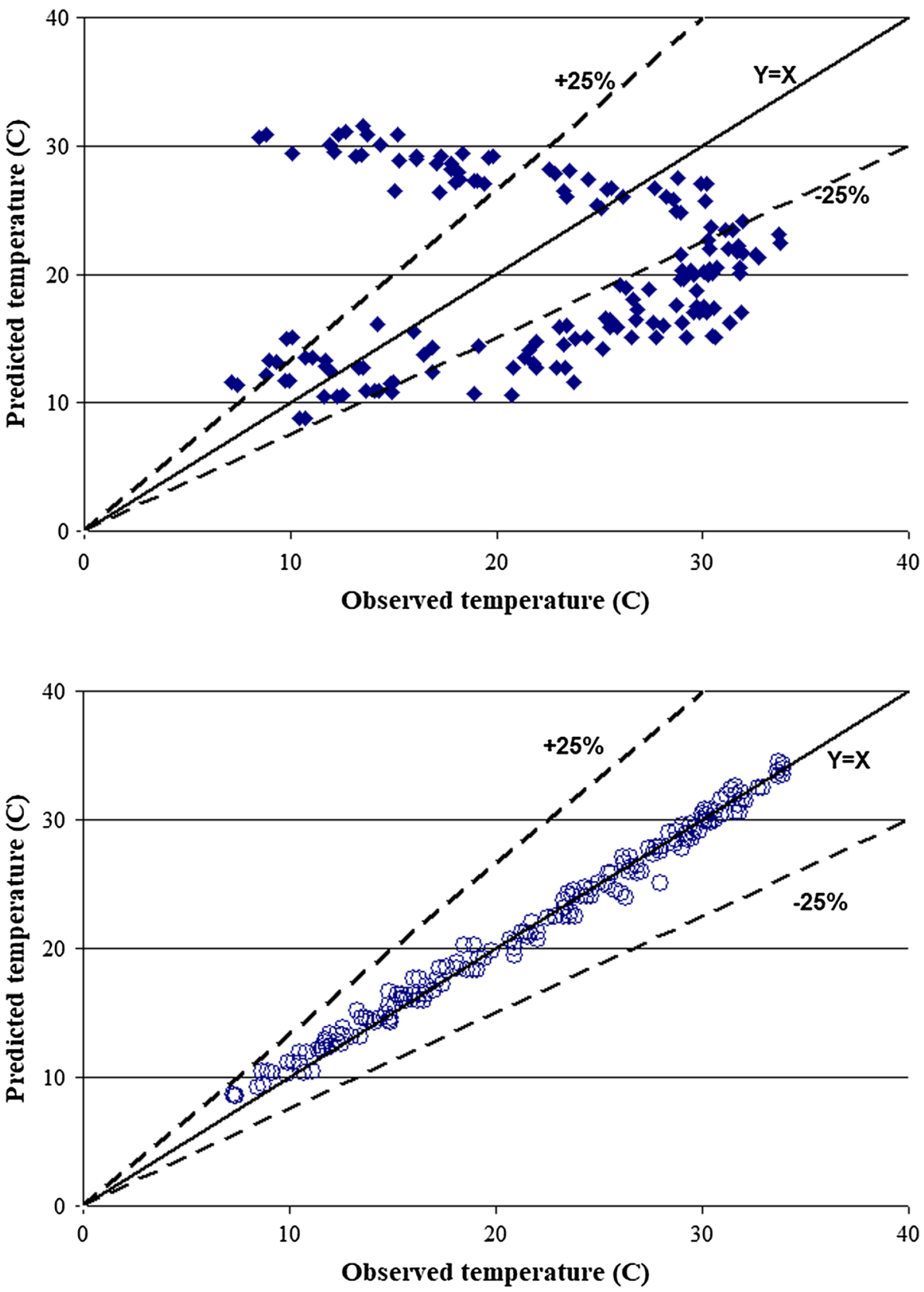

In contrast, Fig. 3 presents the predicted atmospheric temperature from the GEP model. The predicted temperature values were compared against the observed atmospheric temperature values. Unlike the predicted atmospheric temperature values in Fig. 2, Fig. 3 shows an un-scatter plot. They lie closer to the best fit $\left(45^{\circ}\right.$ inclined line) line where predicted values are equal to the observed values. The $R^{2}$ $(=0.91)$ proves the better fitness of the plot. Therefore, it can be clearly seen herein that our GEP model predicts the better atmospheric temperature values using the other climatic parameters.

The performances of the developed ANN and GEP models to predict the atmospheric temperature were compared to test data sets. The comparison can be seen in Fig. 4 .

Figure 4 clearly shows that the GEP model gives better predictions than the ANN model. The ANN model produced the lower coefficient of determination compared to GEP model results and highest RMSE error $\left(R^{2}=0.67\right.$ and 
Fig. 4 Comparison of results obtained from ANN and GEP models

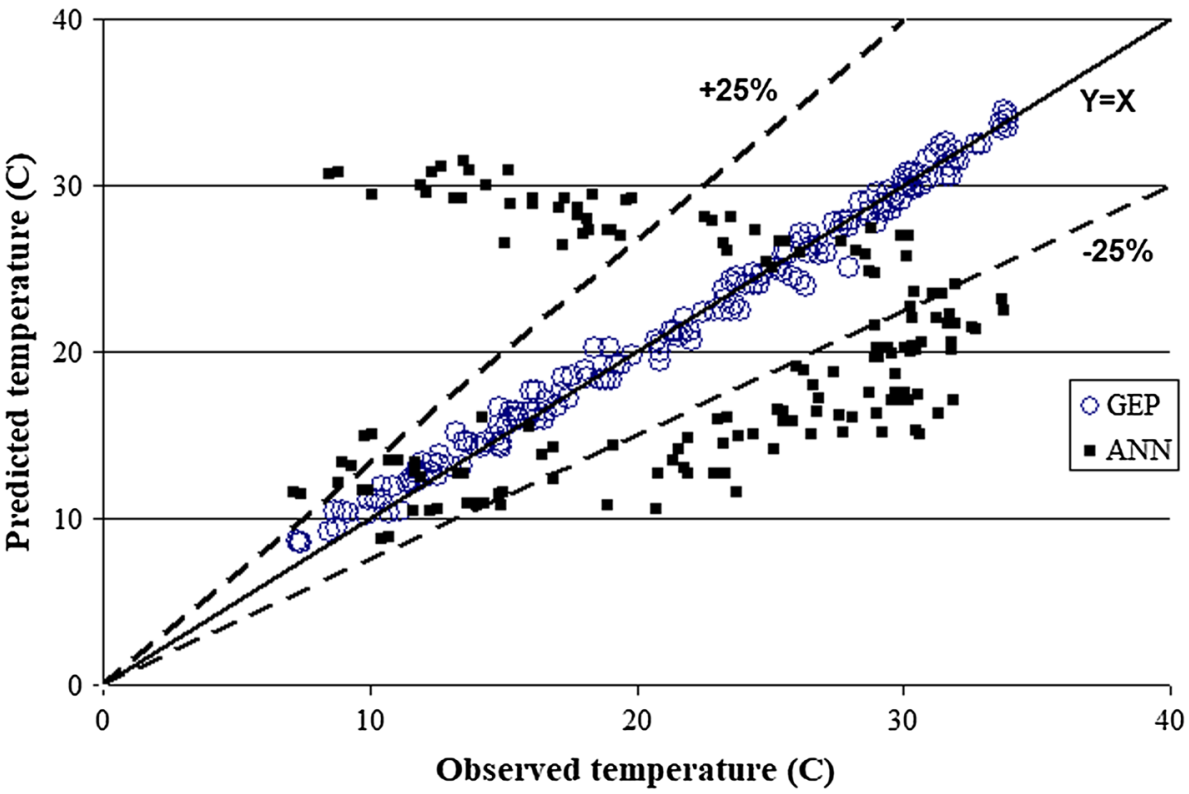

RMSE $=20.179$ ). However, the RMSE error of GEP model predicted that atmospheric temperature is 0.44 . Therefore, it can be clearly concluded herein the GEP model predicts more accurate answers. In addition, ANN model does not provide any governing equations, and this is one of the drawbacks.

\section{Summary and conclusions}

We developed two different generic models (ANN based and GEP based) to predict the atmospheric temperature in Tabuk, Saudi Arabia. Climatic parameters including atmospheric pressure, wind speed, relative humidity and rainfall were used to predict the atmospheric temperature using the models. Results clearly show that the GEP model outperforms the ANN model to predict the atmospheric temperature and suggest that the proposed GEP model is robust and useful for practitioners. Therefore, the GEP model is proposed to estimate the temperatures in agricultural areas in Tabuk under the climate change scenarios. Future research would incorporate the winter and summer months separately in the predictions and would be better to use more input data than 30 years.

Acknowledgements The authors are grateful to Saudi General Authority of Meteorology and Environment protection for providing data for this analysis.

Open Access This article is distributed under the terms of the Creative Commons Attribution 4.0 International License (http://creativeco mmons.org/licenses/by/4.0/), which permits unrestricted use, distribution, and reproduction in any medium, provided you give appropriate credit to the original author(s) and the source, provide a link to the Creative Commons license, and indicate if changes were made.

\section{References}

Abushandi E, Alatawi S (2015) Dam site selection using remote sensing techniques and geographical information system to control flood events in Tabuk city. Hydrol Curr Res 6(1):1-13

Alghamdi A, Moore T (2014) Analysis and comparison of trends in extreme temperature indices in Riyadh City, Kingdom of Saudi Arabia, 1985-2010. J Climatol 2014:1-10

Al-Harbi K (2010) Monitoring of agricultural area trend in Tabuk region-Saudi Arabia using Landsat TM and SPOT data. Egypt J Remote Sens Space Sci 13(1):37-42

Almazroui M, Islam M, Dambul R, Jones P (2013) Trends of temperature extremes in Saudi Arabia. Int J Climatol 34(3):808-826

Athar H (2013) Trends in observed extreme climate indices in Saudi Arabia during 1979-2008. Int J Climatol 34(5):1561-1574

Azmathullah H, Deo M, Deolalikar P (2005) Neural networks for estimation of scour downstream of a ski-jump bucket. J Hydraul Eng 131(10):898-908

Azmathullah H, Deo M, Deolalikar P (2006) Estimation of scour below spillways using neural networks. J Hydraul Res 44(1):61-69

Azamathulla H, Deo M, Deolalikar P (2008) Alternative neural networks to estimate the scour below spillways. Adv Eng Softw 39(8):689-698

Azamathulla H, Ghani A, Zakaria N, Guven A (2010) Genetic programming to predict bridge pier scour. J Hydraul Eng 136(3):165-169

Azamathulla HM, Haghiabi AH, Parsaie A (2016) Prediction of side weir discharge coefficient by support vector machine technique. Water Sci Technol Water Supply 16(4):1002-1016

Barnett J, Adger W (2007) Climate change, human security and violent conflict. Political Geogr 26(6):639-655

Bilhan O, Emin Emiroglu M, Kisi O (2010) Application of two different neural network techniques to lateral outflow over rectangular side weirs located on a straight channel. Adv Eng Softw 41(6):831-837

Ferreira C (2001) Gene expression programming: a new adaptive algorithm for solving problems. Complex Syst 13(2):87-129 
Forster P, Andrews T, Good P, Gregory J, Jackson L, Zelinka M (2013) Evaluating adjusted forcing and model spread for historical and future scenarios in the CMIP5 generation of climate models. J Geophys Res Atmos 118(3):1139-1150

Guven A, Aytek A (2009) A new approach for stage-discharge relationship: gene-expression programming. J Hydrol Eng 14(8):812-820

Guven A, Gunal M (2008a) Prediction of scour downstream of grade-control structures using neural networks. J Hydraul Eng 134(11):1656-1660

Guven A, Gunal M (2008b) Genetic programming for prediction of local scour downstream of grade-control structures. J Irrig Drain Eng 134(2):241-249

Guven A, Aytek A, Yuce M, Aksoy H (2008) Genetic programmingbased empirical model for daily reference evapotranspiration estimation. CLEAN Soil Air Water 36(10-11):905-912

Haghiabi AH, Azamathulla HM, Parsaie A (2017) Prediction of head loss on cascade weir using ANN and SVM. ISH J Hydraul Eng 23(1):102-110

Haines A, Kovats R, Campbell-Lendrum D, Corvalan C (2006) Climate change and human health: impacts, vulnerability and public health. Pub Health 120(7):585-596

Harvell D, Altizer S, Cattadori I, Harrington L, Weil E (2009) Climate change and wildlife diseases: when does the host matter the most? Ecology 90(4):912-920

Hughes T (2003) Climate change, human impacts, and the resilience of coral reefs. Science 301(5635):929-933

Izadifar Z, Elshorbagy A (2010) Prediction of hourly actual evapotranspiration using neural networks, genetic programming, and statistical models. Hydrol Process 24(23):3413-3425

Kalkstein L, Smoyer K (1993) The impact of climate change on human health: some international implications. Experientia 49(11):969-979

Karl T, Trenberth K (2003) Modern global climate change. Sicence 302(5651):1719-1723

Kisi O, Yuksel I, Dogan E (2008) Modelling daily suspended sediment of rivers in Turkey using several data-driven techniques/Modélisation de la charge journalière en matières en suspension dans des rivières turques à l'aide de plusieurs techniques empiriques. Hydrol Sci J 53(6):1270-1285

Koza JR (1999) Genetic programming: on the programming of computers by means of natural selection. The MIT Press, Cambridge

Krishna VL (2014) Long term temperature trends in four different climatic zones of Saudi Arabia. Int J Appl Sci Technol 4(5):233-242

Landeras G, López J, Kisi O, Shiri J (2012) Comparison of gene expression programming with neuro-fuzzy and neural network computing techniques in estimating daily incoming solar radiation in the Basque Country (Northern Spain). Energy Convers Manag 62:1-13

Lee J, Hong S, Chang E, Suh M, Kang H (2013) Assessment of future climate change over East Asia due to the RCP scenarios downscaled by GRIMs-RMP. Clim Dyn 42(3-4):733-747

Malcolm J, Liu C, Neilson R, Hansen L, Hannah L (2006) Global warming and extinctions of endemic species from biodiversity hotspots. Conserv Biol 20(2):538-548

Marotzke J, Forster P (2015) Forcing, feedback and internal variability in global temperature trends. Nature 517(7536):565-570

Mawdsley J, O'Malley R, Ojima D (2009) A review of climate-change adaptation strategies for wildlife management and biodiversity conservation. Conserv Biol 23(5):1080-1089

McDonald K, Brown J (1992) Using montane mammals to model extinctions due to global change. Conserv Biol 6(3):409-415

Mears C, Wentz F (2017) A satellite-derived lower-tropospheric atmospheric temperature dataset using an optimized adjustment for diurnal effects. J Clim 30(19):7695-7718

Parsaie A, Haghiabi AH (2015) The effect of predicting discharge coefficient by neural network on increasing the numerical modeling accuracy of flow over side weir. Water Resour Manag 29(4):973-985

Parsaie A, Haghiabi AH (2018) Water quality prediction using machine learning methods. Water Qual Res J Can 53(1):3-13

Parsaie A, Azamathulla HM, Haghiabi AH (2017) Physical and numerical modeling of performance of detention dams. J Hydrol. https ://doi.org/10.1016/j.jhydrol.2017.01.018

Parsaie A, Ememgholizadeh S, Haghiabi AH, Moradinejad A (2018a) Investigation of trap efficiency of retention dams. Water Sci Technol Water Supply 18(2):450-459

Parsaie A, Azamathulla HM, Haghiabi AH (2018b) Prediction of discharge coefficient of cylindrical weir-gate using GMDH-PSO ISH. J Hydraul Eng 24(2):116-123

Patz JA, Campbell-Lendrum D, Holloway T, Foley JA (2005) Impact of regional climate change on human health. Nature 438(7066):310-317

Pounds J, Bustamante M, Coloma L, Consuegra J, Fogden M, Foster P, La Marca E, Masters K, Merino-Viteri A, Puschendorf R, Ron S, Sánchez-Azofeifa G, Still C, Young B (2006) Widespread amphibian extinctions from epidemic disease driven by global warming. Nature 439(7073):161-167

Quadrelli R, Peterson S (2007) The energy-climate challenge: recent trends in $\mathrm{CO}_{2}$ emissions from fuel combustion. Energy Policy 35(11):5938-5952

Root T, Price J, Hall K, Schneider S, Rosenzweig C, Pounds J (2003) Fingerprints of global warming on wild animals and plants. Nature 421(6918):57-60

Rotstayn L, Plymin E, Collier M, Boucher O, Dufresne J, Luo J, von Salzen K, Jeffrey S, Foujols M, Ming Y, Horowitz L (2014) Declining aerosols in CMIP5 Projections: effects on atmospheric temperature structure and midlatitude jets. J Clim 27(18):6960-6977

Santer B, Painter J, Mears C, Doutriaux C, Caldwell P, Arblaster J, Cameron-Smith P, Gillett N, Gleckler P, Lanzante J, Perlwitz J, Solomon S, Stott P, Taylor K, Terray L, Thorne P, Wehner M, Wentz F, Wigley T, Wilcox L, Zou C (2012) Identifying human influences on atmospheric temperature. Proc Natl Acad Sci 110(1):26-33

Sekercioglu C, Schneider S, Fay J, Loarie S (2007) Climate change, elevational range shifts, and bird extinctions. Conserv Biol 22(1):140-150

Shaltout M, Omstedt A (2014) Recent sea surface temperature trends and future scenarios for the Mediterranean Sea. Oceanologia 56(3):411-443

Shiri J, Marti P, Singh V (2012) Evaluation of gene expression programming approaches for estimating daily evaporation through spatial and temporal data scanning. Hydrol Process 28(3):1215-1225

Shiri J, Kim S, Kisi O (2014) Estimation of daily dew point temperature using genetic programming and neural networks approaches. Hydrol Res 45(2): 165

Simmons A, Poli P, Dee D, Berrisford P, Hersbach H, Kobayashi S, Peubey C (2014) Estimating low-frequency variability and trends in atmospheric temperature using ERA-Interim. Q J R Meteorol Soc 140(679):329-353

Vorosmarty C (2000) Global water resources: vulnerability from climate change and population growth. Science 289(5477):284-288

Yassin M, Alazba A, Mattar M (2016) Artificial neural networks versus gene expression programming for estimating reference evapotranspiration in arid climate. Agric Water Manag 163(1):110-124

Publisher's Note Springer Nature remains neutral with regard to jurisdictional claims in published maps and institutional affiliations. 